International Journal of

Health, Medicine and

Nursing Practice

(IJHMNP)

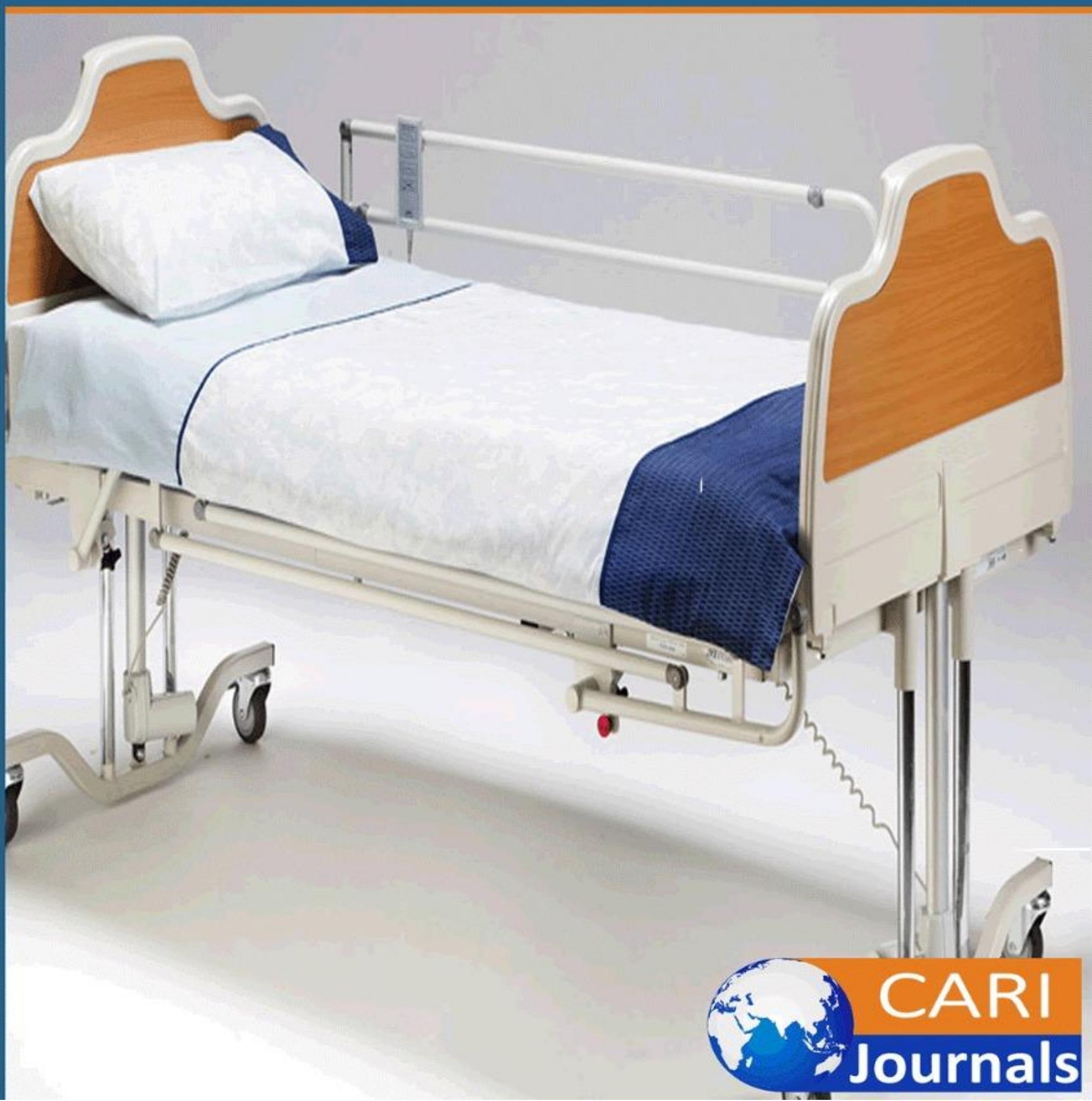




\title{
PERCEPTIONS AND EXPECTATIONS OF NURSING STUDENTS REGARDING DIVERSE TECHNOLOGY BASED NURSING EDUCATION
}

\author{
${ }^{1 *}$ Sana Amanuail \\ Post RN BScN student at LSN (The University of Lahore) \\ Corresponding Author E- mail: alithiagill1234@gmail.com \\ ${ }^{2}$ Kausar Parveen \\ Assistant professor at LSN (The University of Lahore) \\ ${ }^{3}$.Muhammad Afzal \\ Associate Professor at LSN (The University of Lahore)
}

\begin{abstract}
Purpose: Modern nursing care has been described as a blend of high tech and high touch, a term that describes a nurse's traditional caring and compassion combined with 21 st-century health-care technology. Technology can be used in nursing schools to improve learning and student performance. Communication, student participation, and critical thinking are all improved when a technology-infused atmosphere is provided. The study aims to determine the student's perceptions and expectations regarding technology based nursing education.

Methodology: Descriptive cross sectional study was conduct. Students who were full-time students in class, had enrolled their subjects, were current students, and had signed consent to participate in this study were included. Students who refused to participate and were absent from class were not included in the report. Using easy sampling, a sample size of $n=150$ nursing department undergraduate students was taken. A self-administered questionnaire with a 5-point Likert scale was used to collect data. Throughout the study, participants' identities were kept private to ensure human subject safety. Data were analyzed using software SPSS (statistical package for social science studies) version 21.

Results: Demographic characteristics of participants in which Level of the study and programmed of the study included. Minimum students $24(16.0)$ of the $4^{\text {th }}$ year and maximum students 53(35.3\%) from undergraduate $94(62.7 \%)$ and postgraduate $56(37.3 \%)$ were participate

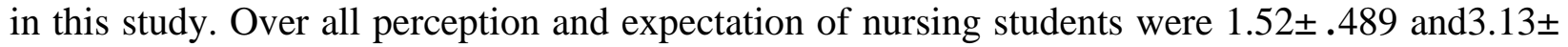
1.32 respectively.

Unique contribution to theory, practice and policy: Educators use technology for academic and communication purposes at campuses, according to nursing students in this research and that their teachers helped them to learn using their own technology devices and online platforms. As a result, more effort and special care are needed to improve nursing students' abilities at the entry level so that they can efficiently use technology for educational purposes.
\end{abstract}

Key words: Perceptions, Expectations, Technology, Nursing Students 


\section{INTRODUCTION}

Modern nursing care has been described as a blend of high tech and high touch, a term that describes a nurse's traditional caring and compassion combined with 21 st-century health-care technology. In almost every aspect of nursing, technology such as computers and measuring equipment is used. Wireless apps are used by many nurses. Nurses of today must be able to not only care for patients, but also use technology safely and appropriately in their daily work. (Greenwood, B., 2019). Teachers are expected to incorporate best teaching practices in the classroom and to ensure that nursing students are inspired and engaged as a result of technological advances, which are transforming the face of nursing education. It is important to address the needs of students in order to achieve effective technology incorporation in education and learning. Since the current generation of students prefers computer skills, professional development, interactive content, and urgency, more technology is being integrated into undergraduate courses to increase student engagement. (Berry, J., 2009).

Technology is used to provide guidance to students and to ensure timely coordination and communication among and between them, as well as with their educators, in the education of health care providers. Borboa et al. (2017) discovered that nursing students used various forms of technology, such as emails, to access online course materials or syllabus, as well as assignments, tests and quizzes, publications, podcasts, and forum discussions. While the effect of technology on health provider education is acknowledged, the literature shows that most efforts have been focused on educating doctors, with dental care, pharmaceutical, and nursing training receiving less attention. Nursing institutions in South Africa are lagging behind other higher education programmes due to a lack of proper incorporation of technology in nursing education. (Maharaj 2015).

Technology can be used in nursing schools to improve learning and student performance. Communication, student participation, and critical thinking are all improved when a technologyinfused atmosphere is provided. All educators should strive to promote and encourage student learning by using instructional strategies and technology to keep students engaged. Another goal is to provide an atmosphere where students can learn safe practices so that when they begin their careers, they will be able to provide high-quality, quality patient care (Harerimana, A., \& Mtshali, N. G., 2019). This can be done in a safe and helpful environment at nursing schools to help students achieve meaningful educational results. This research will help faculty integrate technology into their curricula. Supporting faculty and students in their successful use of technology is the challenge. To encourage practical technology implementation that incorporates digital teaching methods at levels that correlate to learning activities, faculty development and student programming are needed (Williamson, K. M., \& Muckle, J., 2018).

Nursing, the nursing profession, and, of course, nursing education are all impacted by the growth and progress of technology in health care. Nurses play a critical role in incorporating, integrating, and using technology in clinical practises, such as identifying and acting on the effects of patient-related devices and surveillance equipment, as well as the efficient use of electronic health records (Barnard, 2017). Technological technologies are constantly evolving and are critical in addressing current and future health-care issues. Technological awareness, or the ability to comprehend and use technology, is becoming an increasingly important aspect of a 
nurse's skill set (Kjøllesdal, 2010; Risling, 2017). The novel possibility of using patient-reported outcome reporting is one example. The nurse obtains accurate information that can be used to measure progress and communicated and addressed with the patient during appointments by evaluating the patient's progress in care over time using questionnaires that provide a clinical reporting system in the appointment. (Nes, A. A., 2021). While the use of technologies in nursing education holds promise, many obstacles have been identified to stymie its implementation, including slow internet, a lack of ICT literacy, and a loss of enthusiasm among faculty and students. Moreover, many instructors and students lack ICT support and specialized skills to use technology, which is a barrier to teaching and learning in higher education. Academics are also resistant to change, according to the literature, because they do not see the advantages of emerging developments in education (Bello et al. 2017; Harerimana et al. 2016).

While there has been a boom in the use and use of technology by nurses in the clinical environment, research on its incorporation into nursing education settings has yielded little results. However, over the last few years, there has been a rise in the use of technology in clinical practice, which has changed the way instructors share services and involve students. To promote active learning and meaningful interactions, nursing schools are changing paradigms by incorporating technology into the teaching and learning processes. The use of technology in nursing practice has been shown to be helpful for student nurses in previous studies. (Muckle, J., 2018). Many developing nations should priorities developing the competencies of nursing faculty and students, as well as incorporating key ICT capabilities into the nursing education, as technology-based teaching and learning is increasingly used to facilitate creative teaching methods. (Bvumbwe and Mtshali 2018; Maharaj 2015; Mulaudzi et al. 2014). Teachers should be at the frontier of technical advances that involve nursing students in learning and train them for their future careers. It is important to ensure that nursing students and teachers have the requisite ICT skills and are encouraged to use cutting-edge technology while training health care providers. Nursing students and faculty should be given appropriate training and guidance in online teaching and learning, with a focus on Moodle, emails, social media, online resources, and word-processing applications, which are all important in modern technology learning environment. (Ludwig, Nagel, and Lewis 2017; Vargo-Warran 2016)

\section{Problem statement:}

Nursing students indicated that if instructors used technology for a variety of purposes, such as providing course guidance, retaining students' attention, and making links to learning content, such as video or audio, they learned more effectively. The aim of this study was to assess students' perceptions and expectations about technology. It is important for nurse educators to involve students and encourage them to use technology for learning purposes while taking into account their needs and aspirations. To achieve the best learning outcomes, this must be matched with appropriate learning types. (D'Costa, M. P., \& Swarnadas, G. S., 2016).

\section{LITERATURE REVIEW}

Technological devices are portal tools that foster a sense of belonging among students by allowing them to access reference data, communicate more effectively and save time. Technology can be useful, but other considerations, such as versatility and student expectations, 
can affect a student's preparation and capacity to use technology in a realistic way. According to research, one's assertiveness toward technology has a strong effect on one's ability to use it. (Mtshali, N. G., 2019). To effectively incorporate technology into the curriculum, barriers resulting from costs, compatibility, technological problems, and organizational culture must be assessed. When technology is implemented into the classroom, clinical, and/or simulation environments, the timing of its introduction can also be a factor. Newer students may be more enthusiastic about and involved with the implementation of young technologies than upper-level students, who are more concerned with preparation for post-graduation events. Educators should develop a structure to promote the introduction of technologies into the programmer, and it is critical to assess student expectations in order to achieve progress (Greenwood, B., 2019).

The thesis was completed at a prestigious South African university and it used a descriptive quantitative analysis design. 96.7 percent of educators used technology to provide course instruction and encouraged students to use it for creative or problem solving exercises according to nursing students (95.3 percent). They were allowed to use their own technology gadgets $(94.7 \%)$ and web sites by their teachers (94.7 percent). Graduate students (14.41 3.07) were more likely than undergraduate students (15.63 2.54) to assume that nurse educators used technology in the classroom $(\mathrm{U}=1341.00, \mathrm{p}=.044)$. Moodle $(88.7 \%)$, search applications (75.3\%), podcasts and videocasts $(66.7 \%)$, EndNote $(62.7 \%)$, and Turnitin were the most common technologies among nursing students (48.7 percent).

In comparison to 71.2 percent of students from higher academic levels, the majority of students (82.1 percent) from lower academic levels (first and second year) have a good expectation of using technology (third and fourth year). Particularly at the entry level more effort should be put and encouraging students to use different technical resource and ensuring that they are equipped with the necessary skills (Harerimana, A., \& Mtshali, N. G., 2019). According to the findings, more than half of the nursing students $(57.0 \%)$ had a modest level of perception of the quality of nursing courses and advanced technologies, while a minority (10.4\%) had a strong level of perception of the quality of nursing courses. Due to technological advancements, more than half $(52.0 \%)$ of the nursing students surveyed were very good in their total academic achievement, and marginally more than a quarter (26.5\%) of them were outstanding in their total academic achievement. There was a strong statistically significant connection between nursing students' views of technology advances and their nursing course outcomes as well as their academic achievement (Ali, A. Z. F., \& Saad, E. S. S., 2016). The voices and observations of the study participants were crucial in interpreting nursing students' views of their preparation of drug administration with advanced technology, and they laid the groundwork for this study. These opinions were organized into four categories: gaining an understanding, embedding expertise in reality, practicing, and embracing professional obligation. The findings highlight the importance of both the university and clinical placement environments in nursing students' drug management education, as well as the need for further cooperation and advancement between the two. Technology-enhanced learning and simulation should be promoted as teaching and learning tools that facilitate the incorporation of theory and experience over the four years of an undergraduate degree program. (Moloney, M., Kingston, L., \& Doody, O., 2020). 
The study used a quantitative descriptive cross-sectional approach. According to the results, about half of nursing students were dissatisfied with simulation activities, while the majority of them had a high degree of self-confidence in handling simulated scenarios. According to the results of the report, using simulation in conjunction with design elements and teaching methods is a popular solution for clinical nursing education to improve students' comfort and selfconfidence in their learning. The study suggested that nursing curricula incorporate simulated clinical simulation and other adaptive automated learning approaches as an instructional strategy, as well as encouraging nursing colleges to set aside funds for buying equipment and high-fidelity patient simulation manikins (Mohamed, A., \& Mohame, L. K., 2020). Students had favorable attitudes toward the use of technology for learning, regardless of their gender, age, grade level, prior experience, or subject area of interest, according to a study conducted by Kahveci, M. in 2010. Furthermore, students in lower grades were more satisfied with their use of technology than students in higher grades. In contrast to less experienced students, more experienced students were less positive in their use of technology. Female students were less interested in using technology than male students, despite the fact that they did not have a negative outlook about using machines for learning. Finally, students who excelled in science and mathematics were more confident in their abilities to use technology than students who excelled in social science. The thesis was conducted using a descriptive correlative design. Overall, students thought both clinical teaching skills and behaviors were significant, with average ratings ranging from 3.56 to 4.11 and 3.82 to 4.27 . However, giving consistent and timely guidance in patient success $(M=4.11)$ and constantly monitoring their clinical abilities $(M=4.10)$, being frank with the students $(M=4.27)$, and showing outstanding listening skills $(M=4.26)$ is considered as the most relevant successful Clinical Teaching skills and habits. The mean scores of successful clinical technologies were found to have a strong association. The expectations of successful Clinical Teaching skills among students in years II and III varied significantly. Clinical instruction is highly influenced by clinical teachers who demonstrate successful Clinical Teaching skills and instructor behaviors, according to the report.

\section{RESERCH METHODOLOGY}

\section{Study design:}

To identify nursing students' perceptions and attitudes of the use of technology in nursing, a quantitative descriptive cross-sectional research approach was used. The quantitative analysis is used to learn more about specific features within a field of research. Descriptive research illustrates what occurs and may aid in the discovery of new information and concepts (Fox, W. \&Bayat, M.S. 2007)

\section{Study Site:}

The University of Lahore New Campus served as the research location.

\section{Study Setting:}

Setting refers to the more unique locations where data is collected. The research took place in an Allied Health Sciences department, such as the Lahore School of Nursing. 


\section{Target population:}

The University of Lahore's undergraduate and postgraduate students from Allied Health Sciences departments such as the Lahore School of Nursing were the target populations. The sample size was calculated using data from a wider group of University students. The study consisted of both male and female students at the University of Lahore in Pakistan who were adults and in their middle ages. The sample was chosen based on the inclusion and exclusion criteria that were developed. A total of 240 students were enrolled in the study.

\section{Sample size:}

The sample size of the study population was determined using Slovin's sampling formula.

If there are 240 people in total

If $\mathrm{N}=$ Population, $\quad \mathrm{n}=$ Sample size,$\quad \mathrm{E}=$ Margin of error

$\mathrm{n}=\mathrm{N} / 1+(\mathrm{N})(\mathrm{E})^{2}$

$\mathrm{n}=240 / 1+(240)(0.05)^{2}$

$\mathrm{n}=240 / 1+(240)(0.0025)$

$\mathrm{n}=240 / 1+0.6$

$\mathrm{n}=240 / 1.6$

$\mathrm{n}=150$

So the study sample was the 150 students.

\section{Sampling Method:}

For this analysis, a convenient sampling method was used. It is the most straightforward and practical method of locating primary data sources for analysis.

\section{Inclusion Criteria:}

Students who happened to be in the room at the time. Students who were eager to take part. All students in their early to mid-adolescent years. Males and females alike. Both candidates, whether they have graduated or not. Only LSN students are eligible. Full-time students devote themselves to their research and courses.

\section{Exclusion Criteria:}

This research did not include students from other departments. Faculty members were not included in the research. All students who do not want to take part in the activity. There were no students in the classroom. Students who refused to participate in the research

\section{Data Collection Plan:}

The Data Collection Strategy is one of the most important sources for data collection. A selfadministered questionnaire was used to collect data from the study participants. The class, teachers, and students have all given their consent. It was given time and a free hand to be completed and returned. 


\section{Research tool:}

Following institutional acceptance, a quantitative, descriptive study was performed on nursing students using a cross-sectional survey that included a paper-based (Likert scale) questionnaire to explore their perceptions and expectations about the use of technology in nursing education. Those who agreed to take part gave their informed consent. It included all relevant study details as well as a section to document participant consent. To collect and document participant answers, self-reporting questionnaire forms were used. On an individual level, this method is intended to document impressions and expectations of technology-based nursing education checklist. It was divided into three parts, the first of which contained the students' socio demographic information (programme and level of study). On a six-point Likert scale, the second segment included six questions about students' perceptions of educators' use of technology. On a five-point Likert scale, the students' expectations for how nurse educators used technology were represented in the third segment, which consisted of 13 items (Harerimana, A., \& Mtshali, N. G., 2019).

\section{Data Analysis:}

SPSS version 21 was used to analyse the data. Data processing statistical machine applications. The research was descriptive in nature, and all descriptive statistics were collected using SPSS software. The results were calculated using frequency, percentage, mean, median, and standard deviation.

\section{Ethical consideration}

Following approval from the study committee, the project was completed. By way of a permission letter from the department of Lahore School of Nursing, the Ethical Review Board Committee of The University of Lahore and the appropriate Head of Department (HOD) gave their approval to conduct research. Participants were given enough study details with the aid of permission, which was obtained through a consent form attached to the top of the questionnaire. All of the participants gave their consent. Participants were given the option of participating in the study or refusing to do so. Participants also have the option of not mentioning their names. Informing participants reflected on confidentiality. The participants' information would only be used for research purposes. The Nuremberg Code of Ethics safeguarded participants' rights. The subjects' knowledge was kept private and only shared in order to interpret the project's results. On the data collection method, the participants' names were not written.

\section{DATA ANALYSIS}

\section{Descriptive Statistics}

\section{Section 1 Demographic Analysis}


International Journal of Health, Medicine and Nursing Practice

ISSN 2520-0402 (Online)

Vol. 3, Issue No. 2, pp 1-16, 2021

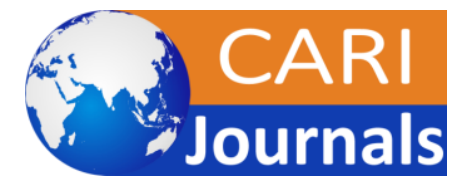

www.carijournals.org

Table and Graph 01

\begin{tabular}{|l|l|l|l|}
\hline \multicolumn{4}{|l}{ Section 1 Demographic Analysis } \\
\hline & \multicolumn{1}{|l|}{$\begin{array}{l}\text { Frequency } \\
(f)\end{array}$} & $\begin{array}{l}\text { Percentage } \\
(\%)\end{array}$ \\
\hline Level of the study & $1^{\text {st }}$ Years & 32 & 21.3 \\
\hline & $2^{\text {nd }}$ Years & 53 & 35.3 \\
\hline & $3^{\text {rd } \text { Years }}$ & 41 & 27.3 \\
\hline & $4^{\text {th } \text { Years }}$ & 24 & 16.0 \\
\hline $\begin{array}{l}\text { Programme of the } \\
\text { study }\end{array}$ & Total & $\mathbf{1 5 0}$ & $\mathbf{1 0 0 \%}$ \\
\hline & Postgraduate & 56 & 62.7 \\
\hline & Total & $\mathbf{1 5 0}$ & 37.3 \\
\hline
\end{tabular}

The above table 1 showed the demographic characteristics of participants in which Level of the study and programmed of the study included. Minimum students $24(16.0)$ of the $4^{\text {th }}$ year and maximum students 53(35.3\%) from undergraduate $94(62.7 \%)$ and postgraduate $56(37.3 \%)$ were participate in this study. 
International Journal of Health, Medicine and Nursing Practice

ISSN 2520-0402 (Online)

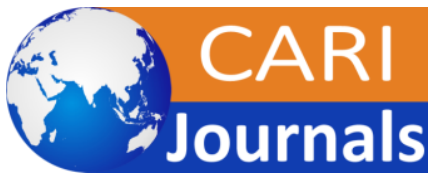

Vol. 3, Issue No. 2, pp 1-16, 2021

www.carijournals.org

Section 2 Nursing students' perceptions of technology

\begin{tabular}{|c|c|c|c|c|}
\hline Sr\# & Questions & $\begin{array}{l}\text { Yes } \\
f(\% \text { age })\end{array}$ & $\begin{array}{l}\text { No } \\
f(\% \text { age })\end{array}$ & $\begin{array}{l}\text { Total } \\
f(\% \text { age })\end{array}$ \\
\hline 1 & Deliver course instructions & $86(57.3 \%)$ & $64(42.7 \%)$ & $\begin{array}{l}150 \\
(100 \%)\end{array}$ \\
\hline 2 & maintain students' attention & $86(57.3 \%)$ & $64(42.7 \%)$ & $\begin{array}{l}150 \\
(100 \%)\end{array}$ \\
\hline 3 & $\begin{array}{l}\text { make connections to the learning materials } \\
\text { (audio or video) }\end{array}$ & $52(34.7 \%)$ & $98(65.3 \%)$ & $\begin{array}{l}150 \\
(100 \%)\end{array}$ \\
\hline 4 & $\begin{array}{l}\text { use their own technology devices to deepen } \\
\text { their learning experience }\end{array}$ & $87(58.0 \%)$ & $63(42.0 \%)$ & $\begin{array}{l}150 \\
(100 \%)\end{array}$ \\
\hline 5 & $\begin{array}{l}\text { use online platforms to communicate with } \\
\text { themselves or other students in/outside the } \\
\text { school }\end{array}$ & $60(40.0 \%)$ & $90(60.0 \%)$ & $\begin{array}{l}150 \\
(100 \%)\end{array}$ \\
\hline 6 & $\begin{array}{l}\text { use technology for creative or critical } \\
\text { thinking tasks }\end{array}$ & $54(36.0 \%)$ & $96(64.0)$ & $\begin{array}{l}150 \\
(100 \%)\end{array}$ \\
\hline
\end{tabular}

The above table 2 showed that $86(57.3 \%$ ) of the nursing students said yes advance technology deliver course instructions while 64(42.7\%). Maximum of nursing students $86(57.3 \%$ ) said yes technology could maintain student's attention during lectures while 64(42.7\%). Uses of their own technology devices to deepen their learning experience were good in the perception of nursing student $87(58.0 \%)$ said yes meanwhile 63(60.0) said No

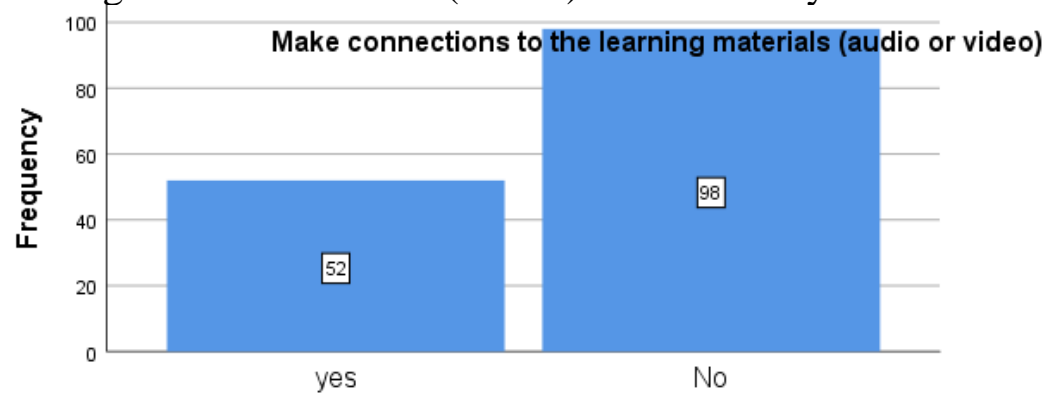

Make connections to the learning materials (audio or video) 
International Journal of Health, Medicine and Nursing Practice

ISSN 2520-0402 (Online)

Vol. 3, Issue No. 2, pp 1-16, 2021

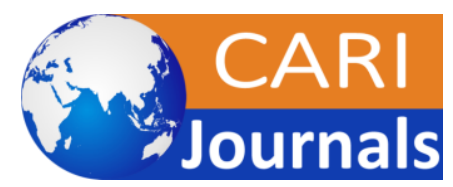

www.carijournals.org

Due to network issues, signals issue 90(60.0\%) students said NO online platforms cannot communicate with themselves or other students in/outside the school mostly students belong from remote or rural areas only 60(40.0) said yes it can communicate themselves. 96(64.0\%) students said No use technology for critical thinking or creative tasks only 54(36.0) said yes.

\begin{tabular}{|c|c|c|c|c|c|c|c|}
\hline Sr\# & Questions & $\begin{array}{l}\text { Never } \\
f(\% \text { age })\end{array}$ & $\begin{array}{l}\text { Rarely } \\
f(\% \text { age })\end{array}$ & $\begin{array}{l}\text { Occasionally } \\
f(\% \text { age })\end{array}$ & $\begin{array}{l}\text { frequently } \\
f(\% \text { age })\end{array}$ & $\begin{array}{l}\text { Very } \\
\text { frequently } \\
f(\% \text { age })\end{array}$ & $\begin{array}{l}\text { Total } \\
f(\% \text { age })\end{array}$ \\
\hline 1 & $\begin{array}{l}\text { Learning } \\
\text { management } \\
\text { system } \\
\text { (Moodle) }\end{array}$ & $39(26.0 \%)$ & $43(28.7 \%)$ & $11(7.3 \%)$ & $29(19.3 \%)$ & $28(18.7 \%)$ & $\begin{array}{l}150 \\
(100 \%)\end{array}$ \\
\hline 2 & $\begin{array}{l}\text { Reference } \\
\text { management } \\
\text { software such } \\
\text { as Endnote }\end{array}$ & $16(10.7 \%)$ & $18(12.0 \%)$ & $30(20.0 \%)$ & $48(32.0 \%)$ & $38(25.3 \%)$ & $\begin{array}{l}150 \\
(100 \%)\end{array}$ \\
\hline 3 & $\begin{array}{l}\text { Turnitin to } \\
\text { detect } \\
\text { plagiarism }\end{array}$ & $11(7.3 \%)$ & $22(14.7 \%)$ & $21(14.0 \%)$ & $46(30.7 \%)$ & $50(33.3 \%)$ & $\begin{array}{l}150 \\
(100 \%)\end{array}$ \\
\hline 4 & $\begin{array}{l}\text { Podcasts and } \\
\text { videocasts } \\
\text { (record lectures } \\
\text { for later use or } \\
\text { review) }\end{array}$ & $15(10.0 \%)$ & $25(16.7 \%)$ & $28(18.7 \%)$ & $46(30.7 \%)$ & $36(24.0 \%)$ & $\begin{array}{l}150 \\
(100 \%)\end{array}$ \\
\hline 5 & $\begin{array}{l}\text { Social media as } \\
\text { a teaching and } \\
\text { learning tool }\end{array}$ & $59(39.3 \%)$ & $27(18.0 \%)$ & $23(15.3 \%)$ & $23(15.3 \%)$ & $23(15.3 \%)$ & $\begin{array}{l}150 \\
(100 \%)\end{array}$ \\
\hline 6 & $\begin{array}{l}\text { Simulations or } \\
\text { educational } \\
\text { games }\end{array}$ & $13(8.7 \%)$ & $23(15.3 \%)$ & $24(16.0 \%)$ & $50(33.3 \%)$ & $40(26.7 \%)$ & $\begin{array}{l}150 \\
(100 \%)\end{array}$ \\
\hline 7 & $\begin{array}{l}\text { Free, webbased } \\
\text { content to } \\
\text { supplement } \\
\text { course-related } \\
\text { materials }\end{array}$ & $19(12.7 \%)$ & $25(16.7 \%)$ & $28(18.7 \%)$ & $45(30.0 \%)$ & $33(22.0 \%)$ & $\begin{array}{l}150 \\
(100 \%)\end{array}$ \\
\hline
\end{tabular}


International Journal of Health, Medicine and Nursing Practice

ISSN 2520-0402 (Online)

Vol. 3, Issue No. 2, pp 1-16, 2021

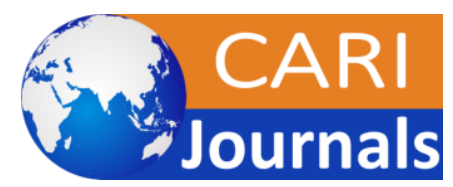

www.carijournals.org

\begin{tabular}{|c|c|c|c|c|c|c|c|}
\hline 8 & $\begin{array}{l}\text { Online tools to } \\
\text { communicate or } \\
\text { collaborate }\end{array}$ & $40(26.7 \%)$ & $49(32.7 \%)$ & $33(22.0 \%)$ & $16(10.7 \%)$ & $12(8.0 \%)$ & $\begin{array}{l}150 \\
(100 \%)\end{array}$ \\
\hline 9 & $\begin{array}{l}\text { Search tools to } \\
\text { find references } \\
\text { or other } \\
\text { information } \\
\text { online for class } \\
\text { work }\end{array}$ & $21(14.0 \%)$ & $35(23.3 \%)$ & $34(22.7 \%)$ & $35(23.3 \%)$ & $25(16.7 \%)$ & $\begin{array}{l}150 \\
(100 \%)\end{array}$ \\
\hline 10 & $\begin{array}{l}\text { Published } \\
\text { electronic } \\
\text { resources (e.g. } \\
\text { quizzes, } \\
\text { assignments, } \\
\text { homework, } \\
\text { practical } \\
\text { problems) }\end{array}$ & $16(10.7 \%)$ & $30(20.0 \%)$ & $40(26.7 \%)$ & $38(25.3 \%)$ & $26(17.3 \%)$ & $\begin{array}{l}150 \\
(100 \%)\end{array}$ \\
\hline 11 & $\begin{array}{l}\text { Early-alert } \\
\text { systems } \\
\text { designed to } \\
\text { catch potential } \\
\text { academic } \\
\text { trouble } \\
\text { timeously }\end{array}$ & $16(10.7 \%)$ & $30(20.0 \%)$ & $40(26.7 \%)$ & $38(25.3 \%)$ & $26(17.3 \%)$ & $\begin{array}{l}150 \\
(100 \%)\end{array}$ \\
\hline 12 & $\begin{array}{l}\text { Software to } \\
\text { create videos or } \\
\text { multimedia } \\
\text { resources }\end{array}$ & $26(17.3 \%)$ & $32(21.3 \%)$ & $35(23.3 \%)$ & $32(21.3 \%)$ & $25(16.7 \%)$ & $\begin{array}{l}150 \\
(100 \%)\end{array}$ \\
\hline 13 & $\begin{array}{lr}\text { Basic } & \text { ICT } \\
\text { literacy } & \text { with } \\
\text { digital devices }\end{array}$ & $20(13.3 \%)$ & $17(11.3 \%)$ & $35(23.3 \%)$ & $40(26.7 \%)$ & $38(25.3 \%)$ & $\begin{array}{l}150 \\
(100 \%)\end{array}$ \\
\hline
\end{tabular}

Above table 3 showed that out of 150 nursing students only 28(18.7\%) of the participants very frequent Learning management system (Moodle), 29(19.3\%) of the students just frequent learn, $11(7.3 \%)$ of the nursing students occasionally learn, $43(28.7 \%)$ of the respondents rarely learn while 39(26.0\%) of the nursing students never learn from it. Question 2 showed that 48(32.0\%) of the nursing students expect that reference management software such as Endnote were used in 
there learning technology, 38(25.3\%) of the students were very frequent learn, 30(20.0\%) of the participants occasionally learn, $18(12.0 \%)$ of the nursing students were rarely learn while $16(10.7 \%)$ of the respondents never learn from this software. Question 3 showed that 50(33.3\%) of the students expectation were that Turnitin to detect plagiarism from their learning contents while minimum students 11(7.3\%)expectations were plagiarism never detected from their contents. In question 4 maximum of the nursing students $36(24.0 \%)$ were very frequent learn with Podcasts and video casts (record lectures for later use or review), 46(30.7\%) of the students were frequent learn, $28(18.7 \%)$ of the nursing students occasionally learn, $15(10.0 \%)$ of the respondents were rarely learn while $25(16.7 \%)$ of the nursing students were occasionally learn from it. In Question 5 59(39.3\%) of the nursing students were never said that Social media as a teaching and learning tool, rarely students $27(18.0 \%)$ were showed positive response, some students $23(15.3 \%$ ) showed occasionally responses while some students showed very frequent and frequent 23(15.3\%) respectively. In question 6 showed that through Simulations or educational games $40(26.7 \%)$ of the students very frequent learn, 50(33.3\%) frequent learn, $24(16.0 \%)$ occasionally learn, 23(15.3\%) rarely learn while just $13(8.7 \%)$ were students were never learn from it. In question 7 most of the students 45(30.0\%) were said through Free, webbased content to supplement course-related materials frequent learn, 33(22.0\%) very frequent learn, just minimum students 19(12.7\%) never learn from it. In question 9 respondents were respond very frequent $25(16.7 \%)$ that Search tools to find references or other information online for class work, 35(23.3\%) frequent, 34(22.7\%) occasionally responses while 21(14.0\%) of the students said never.

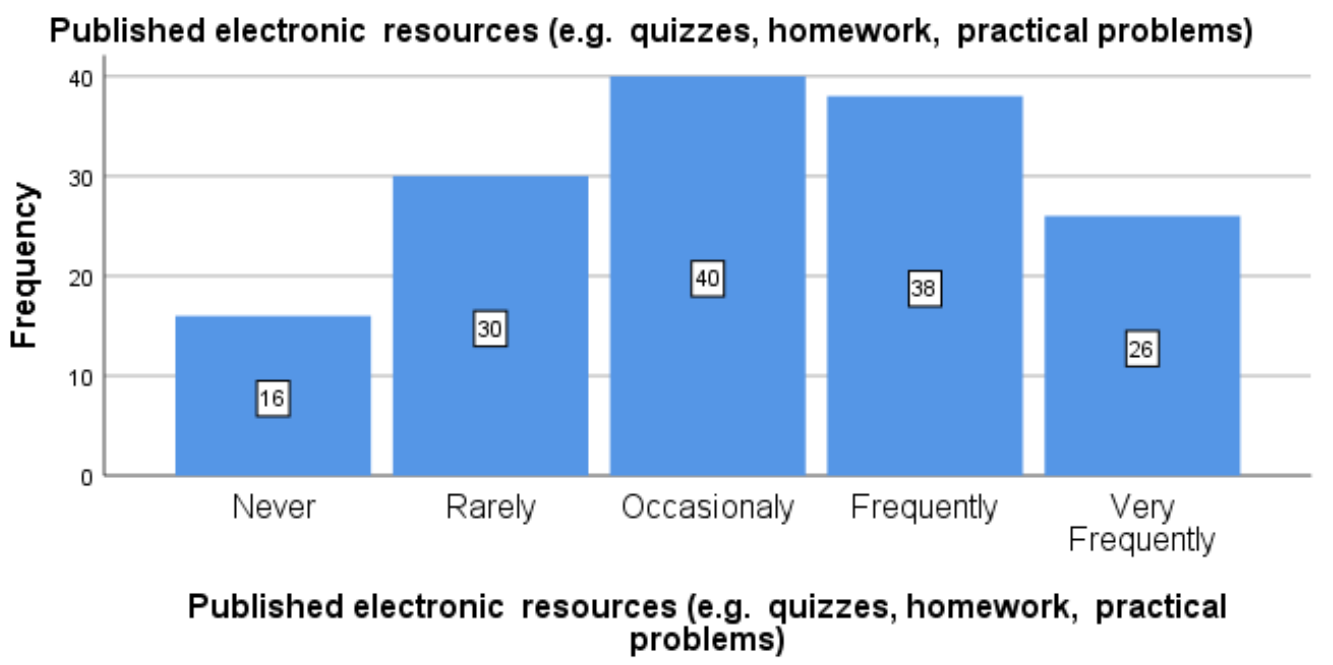

In question 11 most of the students 26(17.3\%) think that Early-alert systems designed to catch potential academic trouble timeously in use of technology in nursing professional, 38(25.3\%) were said it is frequently easy to use, 30(20.0\%) rarely use while $16(10.7 \%)$ never used. 
International Journal of Health, Medicine and Nursing Practice

ISSN 2520-0402 (Online)

Vol. 3, Issue No. 2, pp 1-16, 2021

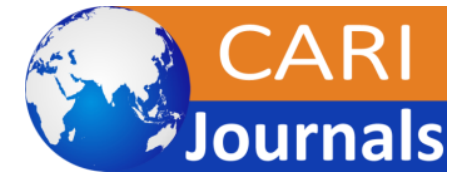

www.carijournals.org

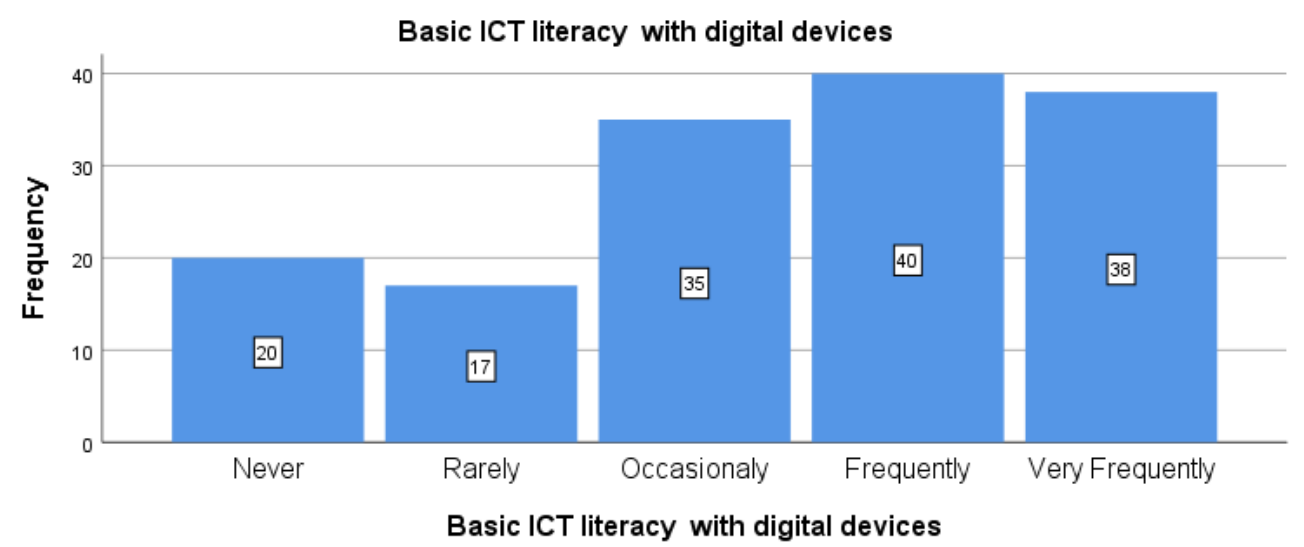

Question 13 showed that students expectation about basic ICT literacy with digital devices, and to use social media, simulations or educational games were frequently and very frequently $40(26.7 \%), 38(25.3 \%)$ respectively. Just only few students $20(13.3 \%)$ were never agreed with it.

Table 5 Summary of descriptive analysis

\begin{tabular}{|l|l|l|}
\hline Variable & Mean \pm S.D & Median \\
\hline Perceptions & $1.52 \pm .489$ & 1.5 \\
\hline Expectations & $3.13 \pm 1.32$ & 3.23 \\
\hline
\end{tabular}

\section{Perceptions}

Summed scores were used to calculate means, median and standard deviation with the purpose of conducting descriptive analysis of demographic data. Sample of 150 participants were used for analysis purpose $($ Mean $=1.52$, and $\mathrm{SD}=.489)$.

\section{Expectations}

Summed scores were used to calculate means, median and standard deviation with the purpose of conducting descriptive analysis of demographic data. Sample of 150 participants were used for analysis purpose $($ Mean $=3.13$, and $\mathrm{SD}=1.32)$. 


\section{Discussion}

A paradigm shift in nursing education is needed to prepare the next generation of nurses for the technology-driven workplace (Bouchaud, Brown, and Swan 2017). Nurse educators must involve students and encourage them to use technology for learning (McKnight et al. 2016); it is critical to understand their needs and aspirations. To achieve the best learning outcomes, however, this must be matched with appropriate learning types .Teachers used technology to provide course guidance $(57.3 \%)$, retain students' attention $(57.3 \%)$, and make links to the learning material, such as audio or video, according to nursing students in this study (93.3\%).

When it came to nursing students' views of the use of technology in nursing education, they believed that their teachers allowed them to bring their own technology devices to class (40.0 $\%)$. They also allowed students to use online tools to connect or interact with teachers or other students within or outside the school $(60.7 \%)$, as well as to use technology for innovative or critical thinking $(36.0 \%)$.

Teachers used technologies to create teaching more relevant and increase student active participation, according to Ghavifekr and Rosdy (2015). Technology is used in nursing education to keep students interested and inspired. According to the literature, technology is used to deliver instructions through internet sites or face-to-face class interactions. (Enriquez et al. 2016). The majority of undergraduate students and students at lower academic levels in the current study had positive attitudes toward the use of technology at school. The majority of undergraduate nursing students had favourable views of the use of ICT to promote learning in nursing education, according to a study conducted by Irinoye, Ayamolowo, and Tijnai (2016). Building on nursing students' positive views of ICT is critical to the use of ICT in nursing, and educators must encourage students to use technology as a learning tool, which would have a positive impact on their academic performance (Austria 2017; Irinoye, Ayamolowo, and Tijnai 2016; Lee et al. 2016).

Nursing students anticipate learning and teaching atmosphere that involves active learning ventures, sharing online video content, and interactive and online participation by faculty in this technological age (Phaneuf 2009). Nurse educators are required to use technology to help teaching and learning, and if they do not, nursing students will be unable to work in an innovation health setting after graduation. The use of computer hardware and specific programmes, word-processing programmes and spreadsheet applications, internet sites and servers, referencing sources, health systems, and emails for correspondence and coordination are among the required competencies in nursing informatics, according to the literature (Hobbs 2002; Masouras 2016; McNeil and Odom 2000).

Developing nursing students' ICT skills helps them gain trust and prevent technology-related dissatisfaction (Edwards and O'Connor 2011; Wilkinson, Roberts, and While 2013). According to the results of this report, nursing students in lower levels had favorable views and high expectations of the use of technology at school as compared to nursing students in higher levels. Students' registration skills should be improved in order for them to be able to use the software successfully for educational purposes, which will improve their academic performance. 


\section{Conclusion:}

Nursing students must be prepared for work in a technology-driven health system, which necessitates the use of technology in nursing education. Educators use technology for academic and communication purposes at campuses, according to nursing students in this research and that their teachers helped them to learn using their own technology devices and online platforms. The results revealed that lower-level student nurses had high standards for the use of technology. As a result, more effort and special care are needed to improve nursing students' abilities at the entry level so that they can efficiently use technology for educational purposes.

\section{Limitation:}

There was several limitation of this study. Firstly, the sample size was small, cross sectional study sample should be large to get the accurate findings of results from participants of the study. Second, the selfreport questions for young students was another limitation in this study, it's mostly effect the study with biasness. The too much small sample size of this study cannot be generalized on the whole population and university.

\section{References:}

Ali, A. Z. F., \& Saad, E. S. S. (2016). Nursing Students' Perception Regarding Quality of Nursing Courses and Its Relation to Their Academic Achievement. American Journal of Nursing, 4(3), 91-99.

Atasoy, H., Greenwood, B. N., \& McCullough, J. S. (2019). The digitization of patient care: a review of the effects of electronic health records on health care quality and utilization. Annual review of public health, 40, 487-500.

Bouchaud, M., Brown, D., \& Swan, B. A. (2017). Creating a new education paradigm to prepare nurses for the 21st Century.

Buabeng-Andoh, C. (2018). New technology in health education: Nursing students' application of mobile technology in the classroom in Ghana. Interactive Technology and Smart Education, 15(1), 46-5.

Chicca, J., \& Shellenbarger, T. (2018). Connecting with Generation Z: Approaches in nursing education. Teaching and Learning in Nursing, 13(3), 180-184.

D'Costa, M. P., \& Swarnadas, G. S. (2016). Students' perceptions of effective clinical teaching skills and teacher behaviours on learning. Manipal Journal of Nursing and Health Sciences (MJNHS), 2(2), 1-8. https://www.britannica.com/technology/technology. Accessed 11 March 2021.

Harerimana, A., \& Mtshali, N. G. (2019). Nursing students' perceptions and expectations regarding the use of technology in nursing education. Africa Journal of Nursing and Midwifery, 21(2), 1-20.

Jensen, H. T., Keogh-Brown, M. R., Smith, R. D., Chalabi, Z., Dangour, A. D., Davies, M., ... \& Haines, A. (2013). The importance of health co-benefits in macroeconomic assessments of UK Greenhouse Gas emission reduction strategies. Climatic change, 121(2), 223-237. 
International Journal of Health, Medicine and Nursing Practice

ISSN 2520-0402 (Online)

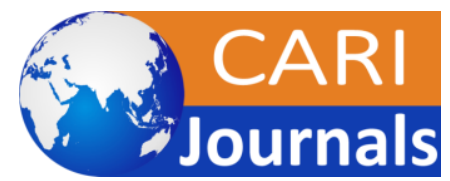

Vol. 3, Issue No. 2, pp 1-16, 2021

www.carijournals.org

Nes, A. A. G., Steindal, S. A., Larsen, M. H., Heer, H. C., Lærum-Onsager, E., \& Gjevjon, E. R. (2021). Technological literacy in nursing education: a scoping review. Journal of Professional Nursing.

McEnroe-Petitte, D., \& Farris, C. (2020). Using gaming as an active teaching strategy in nursing education. Teaching and Learning in Nursing, 15(1), 61-65.

Mohamed, A., \& Mohame, L. K. (2020). Perceived Nursing Students' Satisfaction and SelfConfidence towards the Elements of Clinical Simulation Design and Educational Practice during the Outbreak of COVID-19 Pandemic. Tanta Scientific Nursing Journal, 19(2), 68-98.

Moloney, M., Kingston, L., \& Doody, O. (2020). Fourth year nursing students' perceptions of their educational preparation in medication management: An interpretative phenomenological study. Nurse Education Today, 92, 104512.

Kahveci, M. (2010). Students' Perceptions to Use Technology for Learning: Measurement Integrity of the Modified Fennema-Sherman Attitudes Scales. Turkish Online Journal of Educational Technology-TOJET, 9(1), 185-201.

Lalancette-Hebert, M., Phaneuf, D., Soucy, G., Weng, Y. C., \& Kriz, J. (2009). Live imaging of Toll-like receptor 2 response in cerebral ischaemia reveals a role of olfactory bulb microglia as modulators of inflammation. Brain, 132(4), 940-954.

Lee, H., Min, H., Oh, S. M., \& Shim, K. (2018). Mobile technology in undergraduate nursing education: A systematic review. Healthcare informatics research, 24(2), 97.

Roney, L. N., Westrick, S. J., Acri, M. C., Aronson, B. S., \& Rebeschi, L. M. (2017).

Technology use and technological self-efficacy among undergraduate nursing faculty. Nursing Education Perspectives, 38(3), 113-118.

Williamson, K. M., \& Muckle, J. (2018). Students' perception of technology use in nursing education. CIN: Computers, Informatics, Nursing, 36(2), 70-76.

Yarbro, J., McKnight, K., Elliott, S., Kurz, A., \& Wardlow, L. (2016). Digital instructional strategies and their role in classroom learning. Journal of Research on Technology in Education, 48(4), 274-289. 